\title{
Down but not out: Tourism in Scotland during the Second World War
}

\author{
Blake Morrison
}

This manuscript was prepared under the supervision of Professor Kevin James, Department of History, College of Arts.

\begin{abstract}
On September $3^{\text {rd }}$, 1939, Great Britain declared war on Nazi Germany. The war would be long and drawn-out, affecting almost every aspect of Scottish life. Tourism in this time of crisis would undergo drastic changes but would not disappear entirely; like many other facets of life, it adapted to suit the radical new demands of the conflict. Scottish tourism during the Second World War declined from pre-war levels; however, it did not disappear completely, and despite adverse conditions, was able to thrive in certain areas. The promotion of local holidays, combined with the influx of servicemen from various countries, allowed Scotland's tourism sector to continue throughout the war, albeit in a non-traditional manner. In this unique period of Scottish tourism, the Lowlands, instead of the Highlands, emerged as the main tourist destination. It is the goal of this paper to commence the study of tourism in Scotland during the Second World War and to add to the growing field of Scottish tourism history.
\end{abstract}

$\mathrm{T}^{\mathrm{h} e}$ he bank holiday weekend which falls on the first Monday in August of 1939 showed little difference from previous years. Trains were full, roads busy and resorts heavily booked. There was little, aside from the weather, stopping families from enjoying a pleasant vacation. The "continental situation" had deterred travelers from heading to Germany, but encouraged travel to France. Despite the sense of uncertainty looming in the air, many Scottish families thought whatever was to happen could be dealt with better after a relaxing vacation. ${ }^{1}$ Less than one month later, on September $3^{\text {rd }}$, 1939, Great Britain declared war on Nazi Germany, in response to the invasion of Poland. The war would be long and drawn-out, affecting almost every aspect of Scottish life. Tourism in this time of crisis would undergo drastic changes but would not disappear entirely; like many other facets of life, it adapted to suit the radical new demands of the conflict. Scottish tourism during the Second World War declined from pre-war levels; however, it did not disappear completely, and despite adverse conditions, was able to thrive in certain areas. The promotion of local holidays, combined with the influx of servicemen from various countries, allowed Scotland's tourism sector to continue throughout the war, albeit in a non-traditional manner. In this unique period of Scottish tourism, the Lowlands, instead of the Highlands, emerged as the main tourist destination.

Many historians of travel and tourism are quick to dismiss the war years. All too often books will encompass long time periods only to abruptly end in 1939. In many cases no more than a paragraph is written on the topic. It is assumed by most historians that wartime rationing and the need for production rendered holidays during the war impractical. This view, although logical, neglects important developments in the war years that demand scholarly attention, in particular, Scottish tourism during the Second World War. Alastair Durie and Gayle McPherson have examined tourism during the First World War from a Scottish perspective, ${ }^{2}$ while Harvey A. Levenstein and Bertram M. Gordon give excellent accounts of tourism in Paris during the Second World War. ${ }^{3}$ Chris Sladen's article on the 'Holidays at Home' program during the Second World War encompasses all of Britain, but neglects to give specific attention to Scotland. ${ }^{4}$ It is the goal of this paper to commence the study of tourism in Scotland during the Second World War and to add to the growing field of Scottish tourism history.

On August $24^{\text {th }}, 1939$ the British Foreign Office released a statement to travelers on the continent warning them that communications would possibly become difficult in the following weeks. The Office advised that those traveling abroad would find it in their best interests to postpone their holidays until the international situation improved. ${ }^{5}$ It would turn out that these travelers would have to wait another six years before they would vacation on the continent again. The outbreak of World War Two effectively put an abrupt end to continental travel from Scotland. However, at its outbreak, the war had a great impact on vacationers at home as well. Travels within Great Britain, such as daylight cruises to Belfast, were cancelled as war loomed. ${ }^{6}$ Golf competitions were cancelled too; one discouraged columnist summarized 
the situation by stating that "competitions must of course, gradually go by the way of the board under present circumstances [as] the list of cancellations grows in print day by day." "Leisure activities within Scotland were declining to compensate for the predicted demands of war. Facilities were being used for billeting, while those employed in the tourism sector were being called into the forces. ${ }^{8}$ Tourism was clearly not the most pressing concern for the government at this time. However, although the 1939 vacation season was disrupted and cut short by the outbreak of war, it did not stop everyone from having a holiday. In fact, this was the case throughout the entire war. Although severe restrictions were placed on the Scottish population, tourism still occurred but on a smaller scale and in a very different way. Instead of traveling far from home to usual destinations, some families stayed home and enjoyed leisure activities accessible to them without the need for transportation. These events were largely locally-run and encouraged by the government.

As a direct response to the war effort, the Scottish population, especially the working class, was encouraged to stay home for their holidays. Petrol was needed to power the many machines of the British Armed Forces, and was seen as being wasted as vacationers traveled by automobile to distant destinations. Those taking trains were also seen as a burden to the war cause. They occupied valuable space which could be used to transport servicemen within the country. It was also contended that if workers were taking long vacations, they were not creating valuable munitions and other war products. 9

The government initiated many projects with the aim of localizing holidays and putting an end to the "wasteful" behaviour of pre-war vacationing. The "Holidays at Home" program was directly aimed at keeping vacationers at home during the war. During the summer of 1941, the Ministry of Labour and Information launched the program, which encouraged local authorities and voluntary bodies to provide entertainment and events for the general public. It was the ministry's hope that these events would act as a substitute to annual vacations spent far from home. ${ }^{10}$ The success of this program is debatable. While it encouraged numerous wellreceived local events, many thought it did not fully substitute for the annual vacation. The seaside resort or grouse shooting in the Highlands could not be replaced by park concerts and local dances. Many people who had the means of following traditional vacationing practices did so. ${ }^{11}$ However, for the majority of Scots, the Holidays at Home program offered the only vacations they experienced during the war.

The Holidays at Home took many different forms and were organized by many different groups of people. Events often included dancing displays, singing, games, city and bicycle tours, local fairs and sporting events. During the holiday season, such events were numerous, giving locals a broad choice of entertainment. An August weekend in 1944 offered many events for the people of Edinburgh to attend. There were twelve events in the area: dance displays, singing and games for children, a flower show, a swimming gala, live bands and nightly dances. ${ }^{12}$ Edinburgh was the second largest urban center in Scotland and a diverse selection of events was to be expected. Small towns, although not having as many Holidays at Home events, still participated in the program. The townspeople of Middlefield in Falkirk put on a play to entertain themselves. It was popular practice for these stay-at-home holidays to raise money for the war effort. Proceeds from the Middelfield play was used to collect money for the Spitfire Fund - a program through which groups raised money so that a Spitfire fighter plane could be manufactured. ${ }^{13}$ Renina Addison was also trying to raise enough money to buy a Spitfire. Accompanied by five of her friends, and with help from her parents and teacher, Renina put on a variety show with songs, dances and sketches to entertain the people of East Saltoun in East Lothian. Despite being in a small town and also being a young girl, Renina was able to pack the town hall so full that only standing room was left. Though she did not raise enough money for her Spitfire, but did manage to give the town an excellent night of entertainment. ${ }^{14}$ Like many others, Renina's variety show demonstrates the wide range of activities that constituted Holidays at Home. Furthermore, it shows that there existed a range of people organizing these events. The government was relying on volunteer citizens, but the fact that even schoolgirls were organizing them meant that they had achieved widespread popularity.

The effects of the program can be better seen in the larger cities of Scotland. Cities such as Edinburgh were divided into sections; each section would organise events so that people would not have to use transportation to attend them. Edinburgh was divided into five sections - east, north, south, west and center - with each having its own leader. Each district held events such as football (soccer) matches, tug of wars, dancing, treasure hunts, live bands, concert parties and Punch and Judy shows. ${ }^{15}$ However, some events were so popular that they attracted people from all districts. In the second week of August 1942, the Western District Holidays at Home committee held an event at the Edinburgh Zoo. Not only did the event include a trip to the zoo, but a telegram was sent to the King and Queen, as well as the Prime Minister, declaring support and loyalty. That evening, people were treated to song, dance, magic and marionettes. Over ten thousand people from Edinburgh attended this event, which was considered to be a large scale Holidays at Home undertaking. ${ }^{16}$ Few events were as large as this in Scotland; however one week earlier in England, thirty thousand people attended a similar event at the London Zoo. ${ }^{17}$

A large contributor to the Holidays at Home program, not only in Scotland but throughout Great Britain, was the Council for the Encouragement of Music and the Arts. (CEMA). CEMA was established to improve national morale during the war and give unemployed artists and musicians an arena to display their work and perform. ${ }^{18}$ It seemed to be the 
perfect fit for the Holidays at Home program. The demand for local shows would be easily met by the surplus of artists and musicians created by the war. CEMA's concerts were especially focussed on the working class. The Council's goal was to spread 'good music' to the many people who would otherwise not attempt to seek it. They performed concerts at factory canteens; though they were quite different from the quiet concert halls they were used to, the Council believed that more people would benefit from music in this setting. ${ }^{19}$ Many, but not all, concerts were directed at factory workers. Municipal authorities across Britain recruited CEMA musicians to play their popular classical music. In the summer of 1942 , they were playing approximately 100 concerts across Britain a week. ${ }^{20}$ According to British social historian Nick Hayes, CEMA failed to create a mass art audience during the war, which was one of their main objectives. ${ }^{21}$ However, in the context of the Holidays at Home program, it was a big success. They performed thousands of shows for tens of thousands of people, offering entertainment that the general public would otherwise not have been able to see without traveling.

The success of the Holidays at Home program is difficult to measure. Although many events took place and were well attended, it is questionable as to how many people saw them as actual holidays. There is no real evidence that shows the program was able to substitute traditional holidays with those of the stay-at-home variety. Regardless of these facts, wartime travel had decreased. The program still attempted to meet the leisure needs of the Scottish people, and had an important impact on the wider tourism sector.

The government, along with initiating the Holidays at Home program, took many other steps to reduce tourism to distant locations. The rationing of petrol, and campaigns to stop rail use, were deterrents to travel that also aided the military. The rationing of petrol began on September $23^{\text {rd }}$, 1939; only twenty-two days after the war had broken out. ${ }^{22}$ Not only did the restrictions prevent motorists from traveling long distances to vacationing areas, but it also put an end to most 'touring' activities as well. Motorists living outside city limits found themselves unable to drive to work everyday under the allotted petrol rations, let alone use them for leisure. ${ }^{23}$ Furthermore, all automotive events such as car races, hill climbs, and speed events were not granted permits and cancelled. ${ }^{24}$ The rationing not only directly affected leisure events which used petrol, but events which people traveled by automobile to see as well. A number of events had to be cancelled or held less often due to the need to save fuel. This may have had a detrimental impact on the Holidays at Home program, but was deemed necessary. Horse racing was cut to 20 percent of pre-war levels, greyhound racing was relegated to only one day per week, boxing matches were reduced to approximately 10 percent of pre-war levels and professional football matches were only held on Saturdays and holidays. ${ }^{25}$ It is clear that the petrol restrictions reduced travel and traditional leisure activities throughout Scotland during the war.

Although petrol rationing compelled more people to leave their cars at home and use public transport, the government did not want people traveling on trains either. Railways were seen to be vital for the movement of servicemen, workers and freight important to the war cause. The government's attempt to deter vacationers from using the railways went hand-in-hand with the Holidays at Home program. These holidays were often suggested as a replacement for using the trains. Phyllis West, Welfare Officer for Scotland in the Ministry of Labour, in late May of 1942 encouraged workers to make use of "substitute entertainment of various kinds in the towns." ${ }^{, 26}$ However, more effort was needed to keep civilians off the trains. Railway companies were largely responsible for restricting passenger travel. They dissuaded people from traveling using many different techniques. The first and most successful method was simply offering no extra routes during popular vacationing times. For the August bank holiday in 1943, railway companies were offering no more long distance trains than the maximum offered on weekdays and Sundays, as they had been during July one year earlier. ${ }^{27}$ Executive members of railway companies also wanted to accommodate freight due to the war, which meant passenger rail services were decreased. Ronald Matthews, head of the major London rail company L.N.E.R., conceded that due to the increase of freight, passenger services would have to be curtailed. He warned that "lack of consideration on the part of the traveling public to-day may well compel the adoption of drastic restrictive measures." ${ }^{28}$ The commitment of the railway companies is evident in the fact that Matthews acknowledged the stigma of rail travel, even though he headed a major railway company. It would seem, however, that this view was not held by the majority of Scotland's population.

The railway companies did not just limit trains; they took a proactive role in preventing travelers from using their services with advertising campaigns. Advertisements encouraged would-be travelers to stay at home. For example one campaign by the Railway Executive Committee had a soldier asking "Is Your Journey Really Necessary?"29 Another had an image of a man relaxing outdoors with his pipe, contrasting with a crowded train full of servicemen and civilians. The text reads "A seat in the garden's worth two in the train - Spend your holidays at home. Free the railways for forces and urgent war materials." This advertisement, which appeared in The Times, was funded by the four major rail companies in Britain. ${ }^{30}$ Figures from 1940 suggest that these efforts had caused a decrease of 7 percent in passenger rail use compared to the same time in $1939 .{ }^{31}$

The combined efforts of the Holidays at Home program and the restrictions placed on travel decreased the amount of traditional tourism in Scotland. However, despite its best efforts, the government could not prevent everyone from 
traveling to distant vacation destinations. Reasons for the continuation of traditional vacation practices are numerous in Scotland. It is important to note, however, that the previously-discussed attempts to restrict travel were largely successful, and that these failures should not overshadow that fact. It does, however, offer a perspective on why some Scots continued to vacation.

Despite the government's advice to stay at home during the holidays, many people still traveled. Numerous accounts of busy train and bus terminals were common in newspapers during the war. It would seem that the railway companies' decision to maintain the number of trains running during holiday periods only created more congested stations. An account from July of 1942 stated that all train and bus stations in Glasgow were plagued with long queues. Despite trains being packed to capacity, queues were still hundreds of yards long. Railway officials from the Central Station in Glasgow had never seen such long lines in their entire careers. ${ }^{32}$ Another account one year later, during the same holiday weekend, showed once again that people were disregarding the government's wishes, as they traveling far to their reach their holiday destinations. In Edinburgh, there were queues for even the earliest trains. What struck a reporter from The Scotsman quite vividly were the sailors standing in line for the train bound for Glasgow. Clearly people did not take heed of the poster advising that "A seat in the garden's worth two in the train." The situation in Glasgow was much the same that year. Some travelers who were trying to catch trains headed for Perth, Dundee and Aberdeen had to wait overnight, despite having three trains come throughout the day. ${ }^{33}$ It is clear that people were still going on vacation. An account from John Milloy, who was a young boy at the time, seems to reflect this situation well. He remarks that "Despite the war and the government campaign to spend one's holiday at home, we did go away for a holiday every year of the war." 34 John's mother, who anticipated long lines at the bus terminal, made sure to have the family leave at midnight the night before departure, even though their bus did not leave until eight o'clock in the morning. Despite their preparations, when they arrived at the station "there were already a considerable number of people formed in a queue." 35 John's experience was typical during the war. The failure of measures taken to prevent vacationing, however, can also be explained.

The premise of the Holidays at Home program was to provide an adequate vacation for residents of a certain location so they would not have to seek a vacation elsewhere. Undoubtedly, many people felt the need for a change of scenery in order for them to truly relax and have a good time. Dances in the park and trips to the zoo were excellent daytrips; however after they were over and the stay-at-home vacationer returned, there were still household chores to be done, along with many other reminders of everyday life. A better understanding of the program's potential for success can be seen by analyzing it, using the idea of distance as a stimulant or deterrent for travel, as put forth by Mayo and Jarvis. ${ }^{36}$ To some, the costs associated with travel make it less desirable; however, to others, long distances make locations seem even more desirable. There may be little difference between the activities done in either the close or far-away location, but the distant location seems more attractive simply because it is farther afield. In this framework, it is understandable why people would still take their vacation outside their own city.

Another reason for the high number of people traveling for vacation in Scotland directly related to the nature of the deterrents. There was nothing in place to punish those people who did travel. The Holidays at Home program entertained people who stayed home, but their holidays would be very similar to that of pre-war times if they did choose to take a traditional vacation. Furthermore, although no extra trains were running during busy holiday seasons, the normal train schedule still serviced locations travelers visited. If vacationers had patience and could cope with busy train stations, little was stopping them from traveling. Furthermore, the negative stigma surrounding travel at this time seems to be limited. Perhaps the opinions of someone calling him or herself 'Noblesse Oblige' in an 1943 'point of view' section of The Scotsman most accurately reflects the views the general public. The writer noted that:

some doubt about all this restriction is growing in many minds. If our A.T.S. (to name a group at random) can get 8-day leave permits to travel from (say) Cornwall to Thurso, Land's End to John o'Groats, why would it be impossible for our even harder-working industrial workers to get train accommodation once a year or so and some prearrangement as to quarters, even if they have to take their own rations with them? This sort of thing seems to me quite unjust and largely unnecessary. ${ }^{37}$

This disillusionment with the service encouraged travel, if the public did not support one of the main arguments the government used to diminish passenger rail traffic. Whether for this reason or others, indifference towards the government's efforts to restrict travel encouraged many Scots to take their vacation far from home.

The war effectively cut off Scottish tourism from the world, except for travel by the British people themselves and by soldiers. Soldiers from Allied countries could be seen in areas all over Britain. By 1943, large numbers of soldiers were seen in Edinburgh. ${ }^{38}$ These soldiers were either stationed in Scotland, or on leave from England or the continent. Early on in the war, men were granted leave for ten days every six months if they were on the continent. If they were stationed in Britain, they could have two weeks every six months or one week every month. ${ }^{36}$ This allowed for plenty of vacation time for these soldiers. After London, Edinburgh was considered one the soldiers' favourite cities 
to visit. An American GI, Charles Taylor, thought the Scottish to be more cheerful and friendlier than their English counterparts. $^{37}$ Furthermore, The Scotsman's war correspondent made reference to Edinburgh's old title as being "the gayest city in Europe" in a report from the continent. $^{38}$ Scotland was indeed a welcome vacation destination for troops during the war.

The most popular venues for these men in Scotland were dance halls and night clubs. These venues were notorious for brawls. Often French, Dutch, Norwegian, Polish and British soldiers would unite and start trouble with the Americans. ${ }^{39}$ Indeed, the soldiers stationed in Britain had a reputation for being poorly behaved. An influential minister, James Black, reported seeing "scenes of drunkenness in the public streets among young men in uniform, the like which I have not seen in years." 40 The Territorial authorities were quick to acknowledge what Rev. Black saw as an isolated incident. They also added that if Rev. Black counted the number of civilians whom he had seen drunk in the street it "would have given him a due sense of proportion and have discouraged him from making a mountain out of a mole hill." 41 The government's quick response to minimise scandals surrounding the troops was common during the war. This was especially true with American GIs' indiscretions. They were downplayed or ignored in order for the AmericanBritish alliance to stay strong. This leniency shielded the troops from responsibility and reflected a relatively lax attitude towards behaviour that was formally considered 'out of line'. ${ }^{42}$

One way these soldiers would act out was through heavy involvement in sexual tourism. "The only thing that was cheap in Britain were the women," said an American soldier while on leave. ${ }^{43}$ Another soldier recalled that the "the girls were everywhere... they came up to soldiers waiting in doorways and whispered the age old question." 44 By December 1942, venereal disease among Americans stationed in Britain had increased by 70 percent, compared to the start of the war. Cases of gonorrhoea and syphilis soared. $^{45}$ Advertising campaigns began in 1943 to educate the Scottish public about the symptoms and treatments venereal diseases. ${ }^{46}$ It is important to note that sexual tourism on this scale was limited to soldiers. However, these soldiers also participated in many common tourist activities such as visiting castles and museum. The large number of soldiers seeking holidays in the service presented the Scottish tourism sector with a unique opportunity. The sudden influx of travelers kept many hotels open during the war and even allowed for some to prosper. Like the Holidays at Home program, the arrival of these soldiers did not extinguish tourism, but moulded it in a new untraditional form.

Thus far, this paper has explored consumers in the tourist sector. However, in order for the study of Scottish tourism during World War Two to be complete, the producers, or workers involved in the tourist sector, must be analyzed as well. The Holidays at Home program, combined with the restrictions on rail travel and petrol, had a detrimental effect on the majority of the sector. However, the vast number of troops entering Scotland during the war created a large demand for accommodation and attractions that led major urban centers to prosper. Other factors related to the war, such as requisitions and food rationing, proved detrimental to the tourist sector in other districts. In other words, for some the war was a blessing, and for others, a curse.

Despite the constant threat of being bombed during the blitz, people were still vacationing. A clever travel writer, Ashley Courtenay, found a way to capitalize on the danger. She began running advertisements entitled "Sanctuary Hotels" where she would list resorts and hotels that were safe to for tourists. Courtenay could "vouch for good food, good nights, and a blessed sense of...sanctuary." listed with a brief description. In her introduction she presented an inviting memory or evocative statement to entice would-be travelers. For example, she reminisced, while sitting in her bomb shelter, of nights spent when the only thing she could hear outside was birds singing, a light stream or church bells. ${ }^{48}$ The war allowed Ashley Courtenay to find a niche and exploit it, which ultimately was advantageous for her. Many others involved in Scotland's tourist sector did not share her success.

Also, petrol was not the only commodity to be restricted during the war. Many other common items were rationed too, including food. This had a profound effect on hotels and restaurants throughout Scotland. Hotel menus were criticized for serving lavish meals which were seen as wasteful. Chefs responded by reducing portion sizes, but government action was still taken. ${ }^{49}$ In March of 1941, a bill called the "Meals in Establishment Order" was passed. This legislation limited the amount of food that could be served in one meal; only one main dish and one subsidiary dish could be served. A year later, this order became even more restrictive. Meals in restaurants could not exceed a price of five shillings, and the maximum charge for dancing and cabaret was two shillings and six pence. ${ }^{50}$ This reduced the options available to luxury hotels, which until then, had previously served extravagant dishes. Lobster or salmon could still be served, but without suitable garnishing. Furthermore, no meals could be served after eleven o'clock. ${ }^{51}$ These restrictions were detrimental to many restaurants, but were felt especially hard by the luxury hotels. They were known for fine cuisine, however, under wartime policies, pre-war standards could not be continued and the features that distinguished them from less-luxurious hotels were diminished.

Meal rationing, although detrimental, seems inconsequential compared to what some tourist-facility proprietors faced during the war. The sudden need for administrative buildings and space to billet troops stationed in Scotland resulted in military requisitioning of tourism destinations such as hotels and holiday camps. ${ }^{52}$ Although hotels were entitled to compensation under the 
Compensation (Defence) Act of $1939,{ }^{53}$ it was hardly equivalent to pre-war earnings. These facilities were usually not well maintained and often in a much poorer condition once returned to their owners after the war. The government considered this damage inevitable due to the high number of soldiers with bulky equipment that inhabited them. ${ }^{54}$ However, in certain situations, these requisitions saved hotels. The compensation paid to "tenants whose premises have become in the nature of white elephants to them as a consequence of war conditions" allowed some hoteliers to escape ruin. ${ }^{55}$

The unique situation created by World War Two clearly benefitted some in the tourism sector, and was detrimental to others. A general pattern can be seen from the influx of soldiers and locals staying home. Due to the nature of tourism associated with these two groups, urban centers received almost all tourism during the war. The large populations of Edinburgh and Glasgow, who were encouraged to remain at home for their holidays, would have given patronage to local tourist facilities. Small towns away from urban centers, which normally benefited from tourists exploring the countryside, were largely unvisited during the war. These areas relied instead on the small number of locals to provide business. Such was the case for the Dean Tavern in the small town of Newtongrange, Midlothian. The Dean lost three important employees at the beginning of the war when they were called into service or enlisted voluntarily. The town had a much smaller labour force then a large city and, for the first time, a female tended the bar. Labour shortages were the least of the Deans problems, however. The bar was considerably less busy during the war years and business was the worst it had been in forty years. The Dean was able to remain open, however, many other businesses dependant on tourism did not. ${ }^{56}$

Establishments like the Dean Tavern in remote areas far from urban centers did not benefit from vacationing soldiers. Soldiers stayed in large cities where there was much to do, and very rarely ventured into the far away remote towns of Scotland. It was quite common for soldiers to take bicycles and visit small towns surrounding cities and then return to the pub in the evening. Soldiers did not venture far on their bicycles though. ${ }^{57}$ The Caledonian Hotel in Edinburgh directly benefitted from the influx of troops generally confined to the cities. Although many of the young men employed at the Caledonian were called into service, it seemed to have very little effect on the hotel. The hotel did not have trouble filling their rooms as the streets surrounding it "were awash with serviceman." The Caledonian further catered to American GIs with an American bar which was heavily frequented. ${ }^{58}$ The Caledonian Hotel was able to prosper because it was in a major urban centre which was ultimately the backdrop for tourist activity during the war.

The urban-centered tourism in Scotland during World War Two has led this author to focus largely, if not completely, on the Lowlands. It would seem that the
Highlands, long seen as Scotland's premier touring district, played a comparatively insignificant role in tourism during the war. The vast, sparsely populated region was considerably harder to police then the rest of Scotland. Wartime fears about fifth column activity led to restrictions on seven million acres of land in the Highlands. ${ }^{59}$ To enter these zones, referred to as 'regulated areas', vacationers needed to acquire a passport, which deterred many from traveling there. ${ }^{60}$ The Highlands was not the only area restricted to travelers; a passport was also needed to visit locations along the east coast. The regulated zone started in East Lothian and followed the coastline north to Caithness. ${ }^{61}$ Along these beaches, concrete blocks and other invasion defences could be seen. Similar to the Highlands, tourism was severely affected by these regulations. The Gullane branch of the North British Railway, which ran along Scotland's east coast, was reduced to only ten passenger trains a day, compared to the twenty-two which ran in prewar times. ${ }^{62}$ With these restrictions on travel, the areas available for vacationers were compressed to the inland and west coast regions - a unique development in Scottish tourism.

The assumption that tourism ceased to exist during the Second World War requires heavy qualification. Tourism merely took on forms unique from the experiences Scotland faced at this time. The Holidays at Home program, combined with restrictions on travel, persuaded many Scots to take their vacations without leaving their own towns or cities. Furthermore, the influx of serviceman from around the world looking for a quick vacation presented Scotland with tourists who would have a much different experience during World War Two. It was due to these two groups of people, the Scots themselves and soldiers, that allowed for the tourism sector to survive. Scottish tourism would return to a familiar form during the early 1950s. With American money bolstering the British economy, twenty-five million people enjoyed vacations in $1955 .{ }^{63}$ The six year period, between 1939 and 1945 was an exceptional time for Scottish tourism, still demands further scholarly attention. Continued study of Scottish tourism during the Second World War, with special emphasis on the Highlands, should be a priority for historians; the question that should frame further research on that district is an important one: what caused the reduction of travel in Scotland's premier tourist region during this time?

\section{ENDNOTES}

1 The Times, Saturday August 5, 1939, issue 48376, p. 9, col. A.

2 Alastair Durie and Gayle McPherson, "Tourism and the Outbreak of the First World War: A Scottish Perspective", The Local Historian 29, no. 4 (1999), 240-255.

${ }^{3}$ Harvey A. Levenstein, We'll Always Have Paris: American Tourists in France since 1930 (Chicago: University of 
Chicago Press, 2004); Bertram A. Gordon, "Warfare and Tourism: Paris in World War II", Annals of Tourism Research 25, 3 (July 1998), 616-638.

${ }^{4}$ Chris Sladen "Holidays at Home in the Second World War", Journal of Contemporary History 37, no. 1 (2002), 67-89.

5 The Times, Friday August 25, 1939, issue 48393, p. 14, col. C.

${ }^{6}$ The Scotsman, Monday August 28, 1939, p. 9.

${ }^{7}$ The Scotsman, Tuesday September 5, 1939, p.12.

${ }^{8}$ Ibid.

${ }^{9}$ The Scotsman, Saturday March 7, 1942, p 5.

${ }^{10}$ Sladen, "Holidays at Home", 70.

11 Ibid., 90.

12 The Scotsman, Friday August 11, 1944, p 1.

${ }^{13}$ Andrew Jeffrey, This Present Emergency: Edinburgh, The River Forth and South East Scotland and the Second World War (Edinburgh: Mainstream Publishing, 1992), 145.

${ }^{14}$ Renina Wallace (nee Addison) in Jack Tully-Jackson and Ian Brown. East Lothian at War. Vol. 2 (unknown, East Lothian Library Services, 2001), 78.

${ }^{15}$ The Scotsman, Saturday July 4, 1942, p. 6.

${ }^{16}$ The Scotsman, Thursday August 13, 1942, p. 3.

${ }^{17}$ The Scotsman, Tuesday August 4, 1942, p. 6.

18 Arts Council England. "History of Arts Council England." London: 2004. http://www.artscouncil.org.uk/documents/ information/phpsCTrlM.doc

${ }^{19}$ Nick Hayes "More then 'Music-While-You-Eat'? Factory and Hostel Concerts, 'Good Culture' and the Workers" in 'Millions Like Us'? British Culture in the Second World War, eds. Nick Hayes and Jeff Hill. (Liverpool: Liverpool University Press, 1999), 221.

${ }^{20}$ The Times, Thursday June 25, 1942, issue 49271, p. 2, col. C.

${ }^{21}$ Nick Hayes, "More then 'Music-While-You-Eat'?”, 235.

${ }^{22}$ The Scotsman, Saturday September 16, 1939, p. 9.

${ }^{23}$ The Scotsman, Tuesday September 19, 1939, p. 11.

${ }^{24}$ The Scotsman, Tuesday March 26, 1940, p. 7.

${ }^{25}$ The Scotsman, Friday March 13, 1942, p. 5.

${ }^{26}$ The Scotsman, Saturday May 30, 1942, p. 7.

${ }^{27}$ The Scotsman, Saturday July 17, 1943, p. 6.

${ }^{28}$ The Scotsman, Saturday March 7, 1942, p. 5.

${ }^{29}$ Figure 2.1 "Is your Journey Really Necessary?" in Victor Middleton and L. J. Lickoris,. British Tourism: The Remarkable Story of Growth (London: Elsevier Butterworth Heinemann, 2005), 19.

30 The Times, Thursday June 25, 1942, issue 49271, p. 2, col. F.
${ }^{31}$ The Scotsman, Wednesday April 24, 1940, p. 5.

${ }^{32}$ The Scotsman, Monday July 6, 1942, p. 2.

${ }^{33}$ The Scotsman, Monday July 5, 1943, p. 3.

34 John Milloy. "A Wartime Holiday from Glasgow," The Glasgow Story. http://www.ourglasgowstory.com/ story. php?sid=353

35 Ibid.

${ }^{36}$ The Scotsman, Thursday February 29, 1940, p. 7.

37 Juliet Gardiner, 'Over Here': The GI's Wartime Britain (Great Britain: Collins and Brown, 1992) 92.

${ }^{38}$ The Scotsman, Friday November 21, 1941, p. 7.

${ }^{39}$ Andrew Jeffrey, This Dangerous Menace: Dundee and the River Tay at War (Edinburgh: Mainstream Publishing, 1991), 167.

${ }^{40}$ The Scotsman, Monday August 14, 1939, p. 14.

${ }^{41}$ The Scotsman, Tuesday August 15, 1939, p. 6.

${ }^{42}$ Sonya O. Rose, "Sex, Citizenship, and the Nation in World War Two Britain", American Historical Review 103, no 4. (1998), 1151.

${ }^{43}$ Gardiner, Over Here. 119.

${ }^{44}$ Ibid. 122.

${ }^{45}$ Ibid. 120.

${ }^{46}$ The Scotsman, Saturday February 20, 1943, p. 6.

47 The Times, Saturday June 1, 1940, issue 48631, p. 9, col. A.

48 The Times, Saturday June 29, 1940, issue 48655, p. 8, col. G.

${ }^{49}$ The Scotsman, Saturday May 25, 1940, p. 8.

${ }^{50}$ The Scotsman, Thursday May 14, 1942, p. 4.

${ }^{51}$ The Scotsman, Tuesday June 16, 1942, p. 6.

52 Victor T.C Middleton and L.J. Lickoris, British Tourism: The Remarkable Story of Growth (London: Elsevier Butterworth Heinemann, 2005), 15.

${ }^{53}$ The Scotsman, Saturday September 2, 1939, p. 10.

${ }^{54}$ The Scotsman, Friday September 12, 1941, p. 6.

55 Ibid.

56 Alasdair Anderson, The Dean Tavern: A Gothenburg Experiment (Newtongrange: The Dean Tavern Trust, 1986), unknown page number.

${ }^{57}$ Gardiner. 'Over Here'. 95.

58 Ian Nimmo. Luxury, Edinburgh: The Story of the Caledonian Hotel. (Edinburgh: Caledonian Corporate Press, 1993) 51-53.

${ }^{59}$ The Scotsman, March 30, 1940, p. 12.

${ }^{60}$ The Times, March 26, 1940, issue 48573, p. 5, col. C.

${ }^{61}$ The Scotsman, April 6, 1944, p. 5.

62 Andrew M. Hajducki, The North Berwick and Gullane Branch Lines (Oxford: Oakwood Press, 1992), 117.

${ }^{63}$ Middleton, British Tourism, 20. 